\begin{tabular}{|c|c|c|c|}
\hline \multirow{2}{*}{$\begin{array}{l}\text { Researeh Studies } \\
\text { Anatolia Journal }\end{array}$} & \multicolumn{2}{|c|}{ R\&S - RESEARCH STUDIES ANATOLIA JOURNAL } & \multirow{2}{*}{ 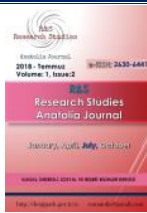 } \\
\hline & www.dergipark.gov.tr/rs & Vol: 1, Issue: 2, pp. 389-393 & \\
\hline
\end{tabular}

Yıldırım, A. (2018). “Logoterapi ve Din”, R\&S - Research Studies Anatolia Journal, Vol:1, Issue:2; pp: 389-393

\begin{tabular}{cc}
\hline \hline Anahtar Kelimeler: Logoterapi, Din, Varoluşsal Yaklaşım $\quad$ Keywords: Logotherapy, Religion, Existential Approach \\
\hline \hline Makale Türü: Derleme \\
\hline \hline
\end{tabular}

\title{
LOGOTERAPİ VE DİN
}

\section{Logotherapy and Religion}

\section{Dr. Ahmet YILDIRIM}

Milli Eğitim Bakanlığı, Ölçme, Değerlendirme ve Sınav Hizmetleri Genel Müdürlüğü, Milli Eğitim Uzmanı, yildirimahmat@yahoo.com Ankara/Türkiye

\begin{tabular}{|c|c|}
\hline $\begin{array}{c}\text { Makale Geliş Tarihi } \\
\text { 04.07.2018 }\end{array}$ & $\begin{array}{c}\text { Yayınlanma Tarihi } \\
30.07 .2018 \\
\end{array}$ \\
\hline ÖZ & ABSTRACT \\
\hline $\begin{array}{l}\text { Logoterapi, bazı psikolojik rahatsılıkların ve varoluşsal } \\
\text { boşluğun çözülmesini hedefleyen ve anlam arayşına } \\
\text { dayanan terapötik bir yaklaşımdır. Viktor Frankl } \\
\text { tarafından İkinci Dünya Savaşı ve takip eden yıllarda } \\
\text { ortaya konulan logoterapi; hümanistik bir yaklaşımı içine } \\
\text { almaktadır. Bu çalışmanın temel amacı Viktor Frankl } \\
\text { tarafından geliştirilen logoterapinin; tarihsel gelişimini, } \\
\text { güçlü ve zayıf yönlerini, logoterapideki bazı temel } \\
\text { kavramları ortaya koymaktır. Buna ek olarak, mevcut } \\
\text { çalışma ile logoterapinin dinle olan bağlantısının ve } \\
\text { ilişkisinin ortaya konulması amaçlanmaktadır. Mevcut } \\
\text { çalışma, bir derleme çalışması olup literatür taramasına } \\
\text { dayalı olarak yürütülmüştür. Çalışma sonucunda, } \\
\text { logoterapinin tarihsel gelişim içinde farklı araştırmacılar } \\
\text { tarafından nasıl ele alındığ ortaya konulmuştur. } \\
\text { Çalışmanın Türkiye'de logoterapi ile ilgili farkındalığın } \\
\text { artırılmasına katkı sağlayacağı düsünülmektedir. }\end{array}$ & $\begin{array}{l}\text { Logotherapy is a therapeutic approach which aims to } \\
\text { resolve some psychological disorders and existential } \\
\text { emptiness. Logotherapy is basically based on search for } \\
\text { meaning. Logotherapy, which was developed by Viktor } \\
\text { Frankl in the Second World War and subsequent years } \\
\text { rests on humanistic approach. The aim of this study is to } \\
\text { explore the historical development, strengths and } \\
\text { weaknesses of logotherapy besides defining some basic } \\
\text { concepts in logotherapy. Moreover, with this study it is } \\
\text { aimed to bring up the relationship between logotherapy } \\
\text { and religion. The current study is a review study which is } \\
\text { based on literature review. In the end of the study, the } \\
\text { researcher defined how logotherapy was addressed by } \\
\text { various researchers in the course of history. This study is } \\
\text { expected to contribute to the raise in the awareness about } \\
\text { logotherapy in Turkey. }\end{array}$ \\
\hline
\end{tabular}

\section{INTRODUCTION}

Logotherapy is a therapy to cope with different life situations. It is named as "recovering through meaning". "Logos" is translated as meaning besides spirit. According to Viktor Frankl's theory of logotherapy; body, mind and spirit are the central dimensions. These three dimensions come together and create human existence. They cannot be separated from one another (Addad and Himi, 2015: 85; Lewis, 2011: 29). In this paper, it was aimed to introduce the historical development of logotherapy and basic concepts in this therapy. Apart from that, the relationship between existential approach and logotherapy was presented besides presenting strategies in logotherapy. Moreover, the relationship among logotherapy, religion and some psychological problems were presented. Lastly, strengths and weaknesses of logotherapy were covered.

\section{HISTORICAL BACKGROUND OF LOGOTHERAPY}

The emergence of logotherapy dates back to Viktor Frankl's experiences in Nazi concentration camp in Auschwitz in Poland. This concentration camp was the biggest concentration camp founded by Nazi Germany. Viktor Frankl's experiences in the concentration camp motivated him to develop "a purpose and a meaning of the life" in order to survive and go on living (Damon, Menon and Bronk, 2003: 119; Hemphill, 2015: 62). Viktor Frankl was born in Vienna in 1905 as a Jewish kid. In 1943, he and his family members, his wife, mother, father and sibling, were taken to Auschwitz concentration camp by Nazi military officers. He spent three years in the concentration camp with the hope to reach his freedom. Ultimately, in 1946 he reached his freedom. However, his family members were not as lucky as Frankl since his mother and father lost their lives in the camp. Before spending time in the 
concentration camp, Frankl worked on his therapeutic technique in 1930s. Even before that while Frankl was a secondary student, he asked questions such as "What meaning does human life have?" (Marseille, 1997: 1). However, his therapy was shaped in the concentration camp (Bahadır, 2000: 7). Viktor Frankl asked existential questions and seeked answer for them in the camp. Many prisoners in the camp, chose to die as they didn't expect that the war wouldn't end. However, Frankl sticked to his wife's images and managed to survive (Hemphill, 2015: 59).

\section{CONCEPTS IN LOGOTHERAPY}

Logotherapy consists of terms such as purpose and meaning. These terms have the driving force to motivate people to do something and even make choices to decide which direction to go in order to live a better life. Logotherapy is a psychotherapeutic approach established by Viktor Frankl. This therapy places "meaning" in the centre and tries to provide therapy for people by enabling them to gain meaning (Bahadır, 2000: 1). Frankl argues that seeking and finding meaning is the biggest motivation of human beings (Hemphill, 2015: 60). According to Frankl, meaning is to go through the life that is personal to the person. He also believes that meaning is searched and found. It is not a gift from God (Marseille, 1997: 4). Furthermore, logotherapy highly regards human beings' physical, psychological and spiritual unity. When logotherapy emerged first, its aim was to assist psychotherapy. However, it reached such a maturity that it went beyond its initial aim. So, it was born as an independent system of therapy (Costello, 2015: 6).

Frankl describes three basic human potentials (Marseille, 1997: 4):

- Self-detachment,

- Self-transcendence and,

- The capability to spiritually be in touch.

Logotherapy holds three basic premises. They are (Miceli, 2011: 3):

- The freedom of will: According to this premise, human beings have free will to choose a positive or negative attitude. It is similar to "fight or flight" attitude.

- The will to meaning: According to this assumption, human beings have a universal, main motivation to find meaning. This is the biggest motivation of people.

- Meaning of life: This assumes that meaning of life may vary from time to time. It is not a general meaning, rather it is specific.

\section{COMPARISON OF LOGOTHERAPY WITH BASIC THERAPEUTIC APPROACHES}

When we look at the relationship among positive psychology, existential approach and logotherapy, we see that they bear commonalities. They all harshly criticize behaviorist and psychoanalytic theories as they have a reductionist view about individuals' values, goals and purposes. Logotherapy and positive psychology, argue that trying to explain people's values, motivations and goals only based on basic drives such as sex and hunger or defence mechanisms is limited. They argue that unconscious mind, defence mechanisms or past behaviors are not sufficient to explain people's expectations or probable lives. They also assert that providing therapy for people by only using past experiences or seeking the problems by only focusing on the past experiences of people reduce people's wholeness. Logotherapy is more future oriented (Damon, Menon and Bronk, 2003: 121; Hemphill, 2015: 60). Furthermore, Costello (2015: 1) also argues that psychotherapy based on behaviorism or psychoanalysis aspires to make people conscious by disclosing or focusing on instinctual experiences while logotherapy tries to focus on spiritual realities by raising awareness. Now, logotherapy is a therapeutic technique used in the United States within "Third Force Psychology" which is used to describe humanistic, transpersonal and existential approaches. The first force was psychoanalysis while the second force was behaviorism (Lewis, 2011: 22).

\section{LOGOTHERAPEUTIC STRATEGIES}

In logotherapy, seeking meaning is the key concept. Seeking meaning is different for each individual and both meaning and the ways of seeking meaning may vary over time. However, Frankl describes three areas that are likely to feed meaning (Hemphill, 2015: 61):

- Work and accomplishment,

- Love and emotional relationships,

- The attitude adopted by the individual when inevitable suffering is present. 
The logotherapist tries to help individuals explore a meaning for their lives in the aforementioned areas. When people find meaning in their lives, they agree to go on their lives as well as getting free of existential emptiness. The purpose is then to find meaning even in the most miserable situations by urging clients to find meaning and be optimistic for their futures.

Miceli (2011: 5) describes Welter's four step approach based on logotherapy:

- Keeping the symptoms distant: In this step, the person is expected to behave as if the symptoms were absent,

- Attitudinal change: In this step, the person is expected to find meaning towards even a situation which is meaningless itself,

- Reduction of the symptoms: After the second step, the symptoms begin to decrease or disappear,

- Orientation to meaning: In the last step, the person is supposed to reach the meaning.

\section{RELATIONSHIP BETWEEN RELIGION AND LOGOTHERAPY}

There might be a relationship between religion and logotherapy. However, the determinant of this relationship is the place where human beings seek meaning in their lives (Hemphill, 2015: 65). If people seek meaning in religious issues, they can go side by side. Moreover, the religions have the aim of regulating the lives of human beings. Logotherapy serves to this aim by rendering people aware of their spirits, unity and guilt. Those who find meaning of their lives agree to live and realize their aims. In this way, they also give proper answers to existential questions.

According to Shantall (2009: 1), faith is essential to find and experience meaning. The aim of logotherapy is to save the individual from hopelessness and meaninglessness and make him/her gain hope. Moreoever, logotherapy aims to give direction to the person in that human life has a purpose. Shantall (2009: 1) also argues that true religion approves the tenets of logotherapy. Conscience is an important factor. By using their consciences, people may learn from their faults. People need to be instructed and taught what is good and what is bad.

\section{USE OF LOGOTHERAPY IN THE TREATMENT OF SOME PSYCHOLOGICAL AND HEALTH PROBLEMS}

Multiple personality disorder requires collaboration from diverse personalities. Logotherapy offers a technique named (Values Awareness Technique) to achieve this task of developing collaboration. This technique based on logotherapy helps personalities recognize values they find meaningful. Hutzell and Jerkins (1990: 92) conducted a study to see whether logotherapy is effective in treating multiple personality disorder. They carried out two case studies. They discovered that "Values Awareness Technique" based on logotherapy may help some patients.

Julom and Guzman (2013: 358) conducted a study in order to examine if logotherapy is effective in diminishing the sense of meaninglessness of paralyzed patients. The researchers helped paralyzed patients to find meaning by using logotherapy based techniques. At the end of the study, they found out that patients might find meaning even if they are faced with an invariable destiny.

Moein and Housyar $(2015: 4,5)$ carried out a study in order to investigate the effectiveness of logotherapy developing self-esteem and adjustment skills of physically disabled people. The design of the study was quasi-experimental. The researchers found out that group logotherapy contributed to the improvement of the adjustment scores of the individuals. In terms of self-esteem, they found that logotherapy improved the self-esteem levels of the participants. The researchers advocate that logotherapy may strongly be used for the improvement of self-esteem and adjustment skills.

Mohammadi, Fard and Heirai (2014: 643, 644) conducted a study in order to examine the effectiveness of logotherapy in depression. They studied with the 36 women suffering from depression. In the framework of their study, they used experimental research design. The researchers found out that logotherapy is effective in improving the hope of life of women suffering from depression.

Shahabi (2016: 240) conducted a study to investigate the effectiveness of logotherapy on cancer patients. The research design was quasi-experimental. The findings of the study indicated that group logotherapy contributed to the improvement of positive and optimistic life orientation. The researchers suggest using logotherapy by therapists so that the patients can seek and find meaning. 
The effectiveness of logotherapy in treating post-traumatic stress disorder was proven by Smith (2012: 9) and Southwick et al. (2006: 171). They found out that post-traumatic stress disorder may be treated with the use of logotherapy.

\section{LIMITATIONS AND STRENGTHS OF LOGOTHERAPY}

The strengths and weaknesses of logotherapy are summarized below (Hemphill, 2015: 63). Strengths of logotherapy are:

- It asks an existential question such as "What is the maning of my life?". Because therapy believes that everybody bears this question in his/her mind.

- It seeks to observe the desire of human beings. The desire of the human beings is to seek meaning and purpose of their lives.

- It acknowledges that every individual is unique and has a unity. The unity is addressed as physical, psychological and spiritual components.

- Logotherapy aspires to offers help for those who cope with the meaninglessness. Some people may not find meaning in their lives. Logotherapy has to do with that specific situation as well. It may offer help to those who cannot find meaning.

When we look at the weaknesses of logotherapy, we see the following weaknesses (Hemphill, 2015: 64):

- Frankl addresses human beings as self-determining. However, human responsibility is limited as God has a lot to do with the lives of human beings. This assumption clashes with the Holy books.

- Frankl classifies human beings as either decent or indecent. However, human beings may be decent to some extent and vice versa. This also clashes with the realities covered in the Holy books.

- Frankl is so sure that human beings can manage their own guilt. He also believes that human beings may choose to be better in their future lives. Both acknowledging the guilt of human beings and also acknowledging that thay can deal with their guilt is kind of contradictory.

\section{CONCLUSION}

Logotherapy is a therapy established by Frankl. It is widely used in especially in Europe as a therapeutic technique. In this study, the historical development and basic concepts of logotherapy were covered. Moreover, the comparison of logotherapy with other therapeutic techniques and the relationship of logotherapy with religion was addressed. Lastly the strong and weak sides of logotherapy were defined. The literature indicates that there is a huge empirical gap in the field of logotherapy. More empirical studies are believed to contribute to the effectiveness of logotherapy.

\section{REFERENCES}

Addad, M. and Himi, H. (2015). Logotherapy - theoretical aspects and field studies in Israel. International Journal of Humanities and Social Science, 5(4), 85-94.

Bahadır, A. (2000). Psikoterapi'de yeni bir yaklaşım: logoterapi ve Viktor Frankl. Uludağ Üniversitesi İlahiyat Fakültesi Dergisi, 9(9), 1-17.

Costello, S. J. (2015). The spirit of logotherapy. Religions, 7(3), 1-12.

Damon, W., Menon, J. and Bronk, K. C. (2003). The development of purpose during adolescence. Applied Developmental Sciences, 7(3), 119-128.

Hemphill, K. (2015). Man's search for meaning: Viktor Frankl's psychotherapy. The Journal of Biblical Counseling, 29(3), 59-68.

Hutzell, R. R. and Jerkins, A. E. (1990). The use of logotherapy technique in the treatment of multiple personality disorder. Dissociation, 3(2), 88-93.

Julom, A. M. and Guzman, R. D. (2013). The effectiveness of logotherapy program in alleviating the sense of meaninglessness of paralyzed in-patients. International Journal of Psychology \& Psychological Therapy, 13(3), 357-371.

Lewis, M. H. (2011). Defiant power: an overview of Viktor Frankl's logotherapy and existential analysis. Defiant Power Solutions.

Marseille, J. (1997). The spiritual dimension in logotherapy: Viktor Frankl's contribution to transpersonal psychology. The Journal of Transpersonal Psychology, 29(1), 1-12. 
Miceli, C. (2011). From the here and now to the now what: an introduction to logotherapy. Presented at NACSW convention, Pittsburgh.

Moein, L. and Houshyar, F. (2015). The effect of logotherapy on improving self-esteem and adjustment in physically disabled people. GESJ: Education Science and Psychology, 5(37), 3-13.

Mohammadi, F., Fard, F. D. and Heidari, H. (2014). Effectiveness of logotherapy in hope of life in the women depression. Procedia Social and Behavioral Sciences, 159, 643-646.

Shahabi, S. (2016). The effect of logotherapy on life orientation of cancer patient. International Journal of Medical Research \& Health Sciences, 5(9), 240-243.

Shantall, T. (2009). Logotherapy and religion. OTSMOT Institute, The Viktor Frankl Center for Logotherapy in Israel.

Smith, A. (2012). Innovative applications of logotherapy for military-related PTSD. Ideas and Research you can use: VISTAS, 1, 1-10.

Southwick, S. M., Gilmartin, R., Mcdonough, P. and Morrissey, P. (2006). Logotherapy as an adjunctive treatment for chronic combat-related PTSD: A meaning-based intervention. American Journal of Psychotherapy, 60, 2(161-174). 